\title{
Toward an Ethnoarchaeomalacology of Achatina in East Africa
}

\author{
Jonathan Walz ${ }^{1 *}$ \\ ${ }^{1}$ Coastal Ecology and Natural Resource Management, School for International Training, Zanzibar, Tanzania. \\ jwwalz.us@gmail.com
}

Abstract Land snail shell is a material commonly identified in the Late Holocene archaeological record of eastern Africa. Typically, archaeologists designate land snail shell as a natural occurrence or as debris produced from human subsistence. Ethnographic observations in lowland northeastern Tanzania show that contemporary communities employ the soft parts and shells of land snails, particularly Achatina fulica, for a range of everyday and special purposes. The array of land snail uses by mixed subsistence farmers and agropastoralists in the area documents the significance of $A$. fulica and other robust land snail species. Present uses of land snails observed in Tanzania offer a set of analogies that, when critically applied, can enrich archaeologists' interpretations of land snail debris in antiquity.

Received July 28, 2016

Accepted May 16, 2017

OPEN ӘACCESS

DOI 10.14237/ebl.8.1.2017.751

Keywords Land snail, Ethnoarchaeology, Malacology, Holocene, Tanzania

Copyright (c) 2017 by the author(s); licensee Society of Ethnobiology. This is an open-access article distributed under the terms of the Creative Commons Attribution-NonCommercial 4.0 International Public License (https://creativecommons.org/licenses/by-nc/4.0), which permits non-commercial use, distribution, and reproduction in any medium, provided the original author and source are credited.

\section{Introduction}

Mollusks have served as critical resources to humans at least since the Pleistocene-Holocene transition. Shell remains are abundant at many Holocene archaeological sites. Further, the remains can be used to infer past environments and environmental changes, human diets, exchange among communities across landscapes and seascapes, bodily adornments, tools (when modified or used), and medicines. However, studies of past mollusks tend to emphasize environments and diets. Moreover, freshwater bivalves and marine mollusks tend to receive greater attention from researchers than terrestrial gastropods. Nevertheless, Lubell et al. (1976) and Goodfriend (1992) employ land snail remains to reconstruct environments in the Mediterranean region in antiquity and other investigators assess land snail impacts to ancient diets in North Africa and Spain (Girod 2003; Guitierrez Zugasti 2011; Lubell 2004; Waselkov 1987). In East Africa, compared to other regions, studies of terrestrial gastropods and their uses among past and present human communities remain underdeveloped.

Items and debris of land snail shell at ancient sites in tropical Africa continue to go underreported or are treated relatively simplistically by researchers.
In East Africa, researchers frequently recover land snail shell at sites attributed to ancient human communities and interpret such remains as natural residues of the environment or as the result of human subsistence (cf. Shipton et al. 2016). Such (non-) treatments of land snail debris undermine other potential meanings and interpretations of land snail shell in the archaeological record (Walz 2010a). As archaeologists begin to address either land snail shell fragments or concentrations (middens or, more specifically, escargoteries) in Late Holocene (post-500 BC) African contexts, they should consider the remarkable analogical potential of contemporary Africans' uses of land snails. The recounted research documents ethnographic uses of land snails by mixed subsistence farmers and, to a lesser extent, agropastoralists who live in lowland northeastern Tanzania. These observations help to build an emergent ethnoarchaeomalacology that attends to the socially embedded nature of land snail finds in archaeological contexts.

\section{Study Region}

At present, a diverse group of land snails populates mainland northeastern Tanzania in the Tanga and Kilimanjaro regions (Emberton et al. 1997; Tattersfield et al. 1998; Verdcourt 1952, 1972). The 


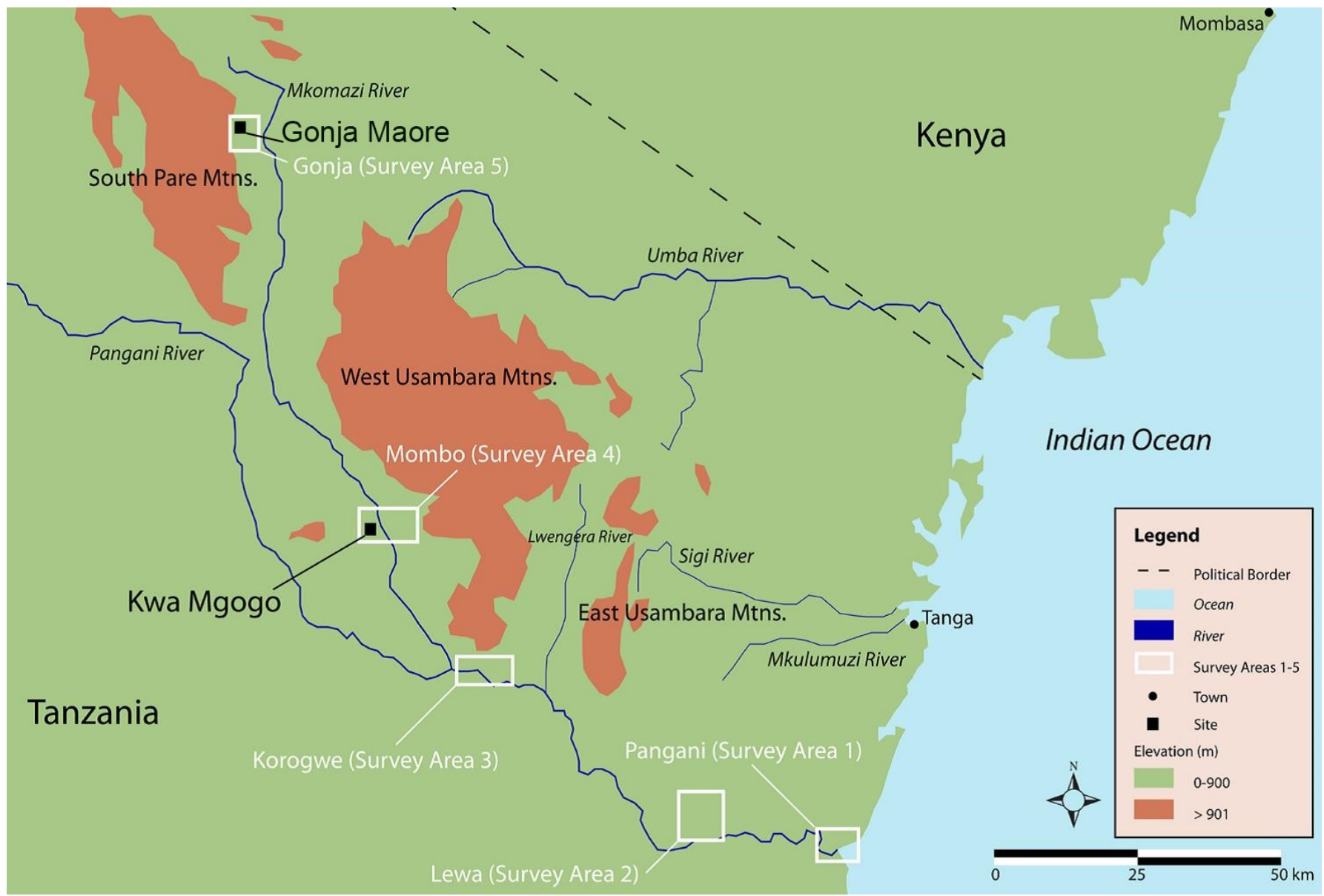

Figure 1 Map of the lower Pangani (Ruvu) Basin in northeastern Tanzania; survey areas 1-5 and sites of Kwa Mgogo and Gonja Maore marked.

mosaic environment of northeastern Tanzania includes a coralline coast abutting the western Indian Ocean, the tropical catchment of the lower Pangani (Ruvu) River Basin, components of the dramatic Eastern Arc Range (the East and West Usambara Mountains and South Pare Hills), and the arid, interior Maasai Steppe. Residents in the region include Swahili town dwellers along the immediate coast, subsistence farmers (Zigua, Pare, and Shambaa communities-_all Northeast Coast Bantu language speakers) in the coastal hinterland, and agropastoralists (Il-Parakuyu communities-Maa/Eastern Nilotic language speakers), who live in the more arid interior, outside of the tsetse fly zone that can threaten stock. There is great diversity in the cultural practices of these populations.

\section{Data Collection and Results}

Data about local communities' use of land snails are derived from three years of observations and activities within and around the Pangani (Ruvu) Basin in the lowland, coastal hinterland of northeastern Tanzania. Interest in land snails and their roles among contemporary East African communities arose as the result of two archaeological activities: 1) a systematic survey of $44 \mathrm{~km}^{2}$ of the landscape, during which living land snails, deceased land snails, and fragments of land snail shell were found on the surface of scores of Holocene Epoch archaeological sites and 2) excavations at two iron-using, farming (also known as "Iron Age") archaeological sites: Kwa Mgogo and Gonja Maore (Figure 1). The two sites date to the late -first and early-second millennia $\mathrm{AD}$, as determined by multiple AMS dates from charcoal samples (Walz 2010b).

The results of systematic surface survey and archaeological excavations yielded evidence of intact and fragmentary land snail shells as well as items made from land snail shell. Collectively, excavations at Kwa 


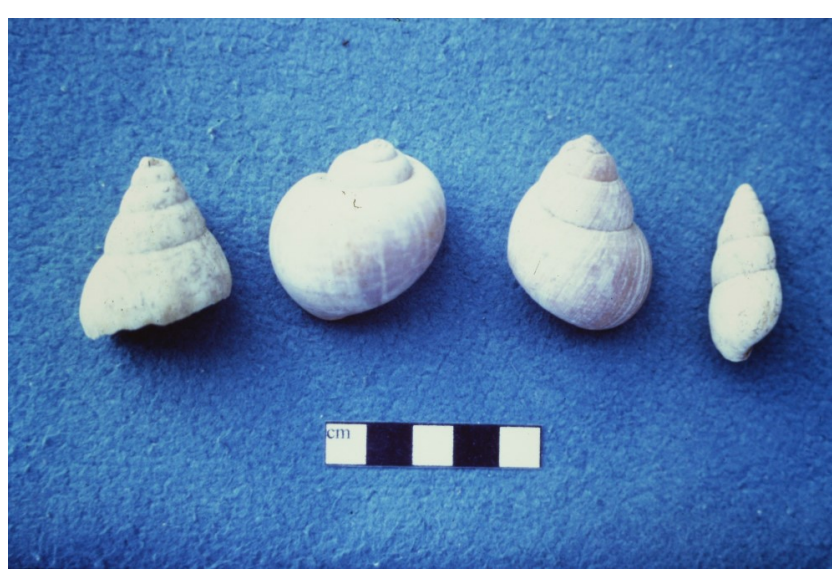

Figure 2 Land snail shell specimens excavated from Kwa Mgogo, Tanzania: (left to right) $A$. fulica (partial), $P$. ovata, L. ovum, and Limicolaria martensiana.

Mgogo (in Korogwe District, Tanga Region) and Gonja Maore (in Same District, Kilimanjaro Region), sites positioned $100 \mathrm{~km}$ and $175 \mathrm{~km}$, respectively, from the Indian Ocean coast, yielded more than $14 \mathrm{~kg}$ of land snail shell, among other archaeological items. At Kwa Mgogo, based on MNI (Minimum Number of Individuals)-determined from the number of shell whorls or opercula discovered of a speciesfieldwork recovered 524 land snails. Nine land snail taxa occur at the site. By weight, most identifiable specimens are Achatina spp.: likely A. fulica, also known as the Giant East African Land Snail.

Other prominent land snail species at Kwa Mgogo include Lanistes ovum and Pila ovata, especially in archaeological strata post-dating AD 900. L. ovum and $P$. ovata are moderately amphibious, requiring fresh water for sustenance and reproduction. Both are gonochoristic. Putatively, ancient residents collected the two mollusk species at nearby perennial or seasonal rivers and consumed them as food and/or used their soft body parts. This interpretation considers the completeness of their shells (whole or near whole and always unmodified, despite their fragility) as compared to the modified and more fragmentary character of the shells of $A$. fulica (Figure 2).

The archaeological assemblages at Kwa Mgogo and Gonja Maore (and other sites in northeastern Tanzania and the abutting area of southeastern Kenya, see Biginagwa 2012; Collet 1985; Soper 1967) include intact shells of $A$. fulica and many fragments of land snail shell that likely result from non-human predation by banded mongoose (Mungos mungo) and various rodents, birds, and carnivorous land snails (Kasigwa et al. 1983). Non-human predation leaves very fragmentary remains of shell clustered in small $(<$ $0.25 \mathrm{~m}$ in diameter) mounds (by M. mungo). Such predation results in individual shells with single or multiple small perforations on the whorls of land snail specimens (by rodents, birds, and carnivorous land snails).

However, most strikingly, these assemblages also include a variety of human-made objects fashioned from the shells of A. fulica, including more than 1600 disc-shaped beads and their production debris. Items of land snail shell include all stages of the bead making process: 1) near whole shells of A. fulica with multiple circular cut-outs, 2) circular bead preforms, 3) pierced circular bead preforms, and 4) completed beads (with smoothed edges made by grinding) (Figure 3a, b). As of yet, however, it is unconfirmed whether land snail shell beads were detached by quartz microliths and smoothed by bead grinders of ceramic, as often is assumed in wider East Africa. Other implements made from the shells of the Giant East African Land Snail include, but are not limited to, pierced ornaments of various shapes and sizes, spoon-like or scoop-like items, and shallow bowls with yet to be determined interior residues, preliminarily interpreted as either food residues, food additives, medicines, cosmetics, mastics, or hunting poisons.

A. fulica regularly grows to more than $20 \mathrm{~cm}$ in length and more than $0.5 \mathrm{~kg}$ in weight. The shell thickness for adult A. fulica in the archaeological assemblage at Kwa Mgogo averages approximately 2 $\mathrm{mm}$. Its high visibility, ease of harvest, and robust shell explain human interests in the Giant East African Land Snail through time. In ethnographic observations, residents in the regional lowlands collect such land snails from agricultural fields, trash middens, and rocky outcrops, localities where A. fulica congregates. Land snails are called konokono (singular, Swahili, a general designation for mollusks) and, less frequently, koa (singular, Swahili, a specific designation for large land snails) (Walsh 2015). The project encountered live and deceased specimens during transect surveys (which the project conducted for archaeological, not malacological, purposes). The natural frequency of $A$. fulica varies based on the season (more common during the rainy season and immediately thereafter), vegetation and soil types, and the presence of substantial human refuse. 

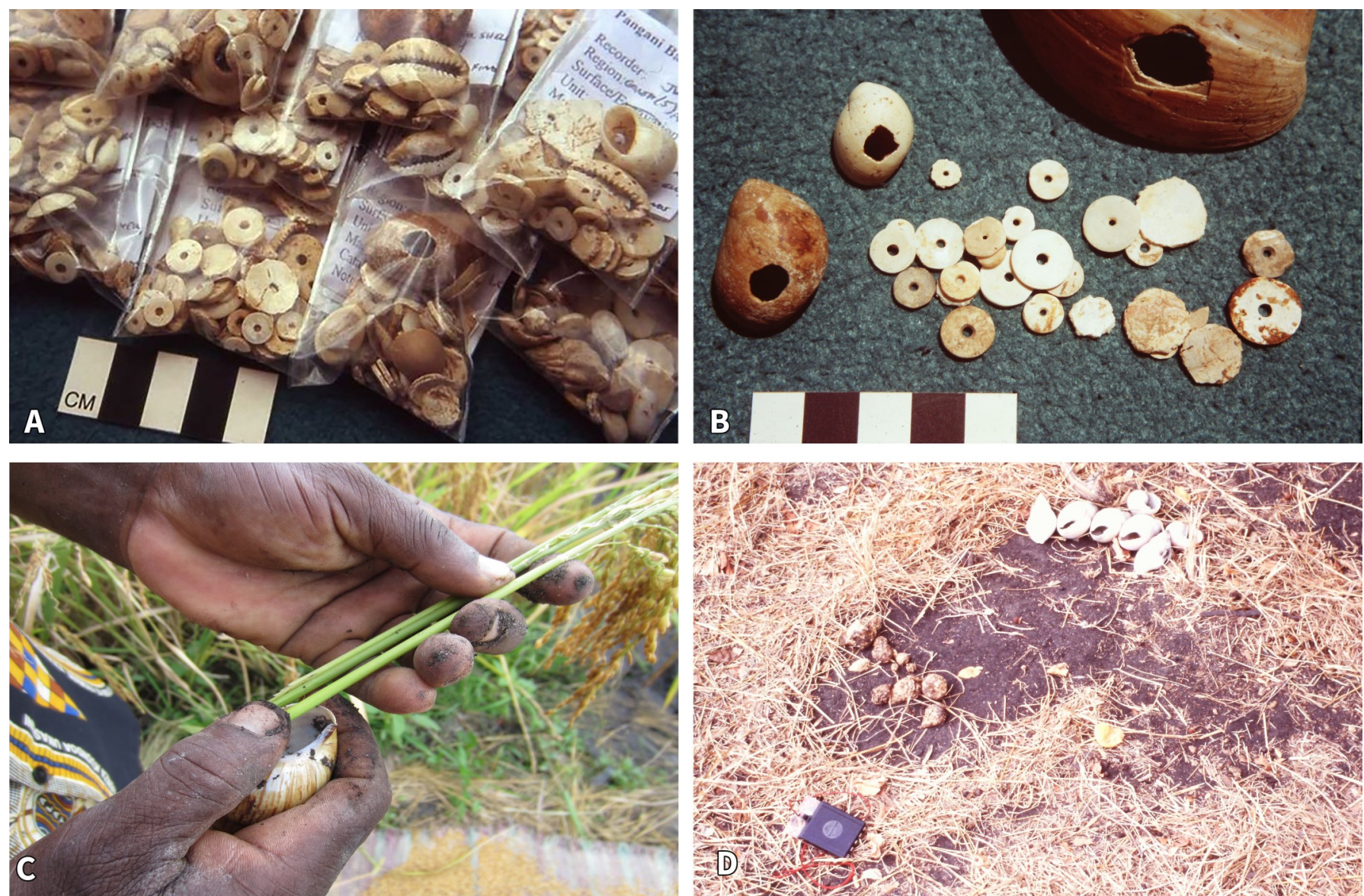

Figure 3 Uses of land snail shells, ancient and modern (clockwise from upper left to lower left): A land snail shell disc beads and marine shells and beads from archaeological contexts; B shells, bead preforms, and finished beads from archaeological contexts; C a modern land snail shell used to harvest rice; D modern shells of $A$. fulica employed in alleged witchcraft $(\mathrm{cm}$ scales or compass for scale; all photos from northeastern Tanzania).

During research in Tanga Region and eastern Kilimanjaro Region, at least one ethnographic case was observed of each of the uses of the Giant East African Land Snail or (less frequently) other land snail species listed in Table 1, either for their shells or soft parts. During structured and unstructured interviews, residents also spoke repeatedly about additional uses of land snails.

\section{Discussion}

Based on ethnographic observations, oral histories and traditions, and limited clues in historical and scientific literature (e.g., Pilsbry 1919 for eastern Central Africa), scholars working in eastern Africa should consider a range of potential interpretations for land snail shell debris at ancient sites. Simplified treatments that lump such finds into categories like "natural occurrence" or "human subsistence" are likely to be partially, if not completely, erroneous.
This is especially the case for large land snails, like $A$. fulica, with more robust and durable shells. For instance, the modified land snail shells excavated at Kwa Mgogo and Gonja Maore indicate a wide range of uses, for example as ornaments and household implements. Patterns of manufacture and items' inferred uses may closely parallel contemporary treatments based on observations of community practices. As with other cases in ethnoarchaeology, such as built architecture and pottery manufacture and use, the veracity of analogical arguments depends largely on the tightness of fit between present analogs and archaeological residues. Regardless of the specific inferences, there will be both similarities and differences in practices tied to land snails across space and through time.

In this region, personal adornments (e.g., beads) and household objects (e.g., spoons) continue to be 
Table 1 Contemporary uses of land snails in lowland northeastern Tanzania.

\begin{tabular}{ll}
\hline Use & Specifics of Use (Form) [Ethnolinguistic Group] \\
\hline Food & as famine food (soft parts; not observed, but evident in oral histories and traditions) [Zigua] \\
as bait for catching freshwater fish (soft parts) [Pare and Zigua] & as latches to secure freshwater fish traps (single modified fragment of shell spire in a "U" shape) \\
[Pare] & to scare birds and other pests from agricultural fields (multiple large shells pierced with a bone tool \\
along the shell lip and hung in contact) [Pare and Zigua] \\
to hoe agricultural fields (single modified fragment of a large shell spire hafted to a wooden handle) \\
[Pare] \\
to cut stems and detach seeds from grain crops, including varieties of rice (single modified small \\
shell) [Zigua] (Figure 3c) \\
to smooth surfaces of unfired pottery (single modified fragment of a large shell spire) [Zigua] \\
as spoons (single modified fragment of a large shell spire with one end wider than the other) [Pare, \\
Shambaa, and Zigua] \\
as containers to carry salt (single large shell) [Pare and Zigua] \\
to mark locations of hunting traps concealed in vegetation (single large shell pierced with a bone tool \\
along the shell lip and hung in a low bush) [Pare] \\
to mark the intersection of two paths where the entrance to one path is hidden (single large shell \\
pierced with a bone tool along the shell lip and hung in a low bush) [Pare and Zigua] \\
to mark the boundaries of agricultural fields (multiple large shells spaced equidistantly) [Pare] \\
as personal adornments (multiple pierced fragments of shell spire suspended on a cord) [II-Parakuyu, \\
Pare, and Zigua] \\
to decorate the exteriors of wattle-and-daub residences of elder men (multiple fragments of shell \\
embedded in daub) [Zigua] \\
to adorn human graves (multiple large shells) [Shambaa and Zigua] \\
as offerings left at spirit dwellings (single or multiple large shells) [Shambaa and Zigua] \\
to call snakes (by blowing), locally represented as ancestors / nature spirits (single modified large \\
shell pierced with a bone tool at the apex; not observed, but evident in oral histories and tradi- \\
tions) [Zigua] \\
to conduct healing and alleged witchcraft (multiple large shells) [Pare, Shambaa, and Zigua] (Figure \\
3d)
\end{tabular}

manufactured from land snail shell. However, the other contemporary uses previously noted offer additional hypotheses to be tested for continuity at Kwa Mgogo, Gonja Maore, and other archaeological sites. As an example, the high frequency of whole shells of $A$. fulica found in and around multiple human burials at Kwa Mgogo may signal that, like the Zigua, ancient communities employed land snails to adorn graves and/or to venerate ancestors. Narratives about mythical serpents, represented as nature spirits and ancestors in contemporary Zigua cosmology (Walz 2010b), also link to finds of concentrated and modified snake vertebrae at and near these same burials at the site. Thus, preliminary indications also designate snakes as significant to communities in antiquity. In oral traditions, interviewees mention the use of a large land snail shell (modified at its apex) to call serpents. The archaeological context of such finds within the overall site lay-out and in relation to archaeological features, such as burials, can help to substantiate oral evidence. The modification of certain land snail shells, like those employed to call serpents, at Kwa Mgogo should be examined to test this hypothesis about cosmology across time.

Such methodological approaches present new possibilities for investigating the longevity of ritual practices by closely examining A. fulica shells in the archaeological record. In addition, archaeologists should look beyond the remarkable richness and variability of communities' uses of the soft parts and 
shells of land snails to improve their ability to interpret sites. Detailed taphonomic studies of sites with copious land snail shell debris (including those with middens or escargoteries) will enable more precise interpretations of the meaningfulness of distinct patterns of accretion (e.g., Matteucci et al. 2007). Focused actualistic studies of, say, banded mongoose behavior and its impact on land snail shell distribution is one recommendation (Kasigwa et al. 1983). In the domain of culture, human objects fashioned from land snail shell may be reinterpreted with new significance (also see Claassen 1998). In this light, Brown (1995) proposes that land snail shell was used as a flux for iron smelting in southern Kenya more than 500 years ago. Regardless, the application of contemporary ethnographic observations to ancient sites and residues motivates transformed and enriched interpretations of A. fulica and other land snail remains in East Africa.

\section{Conclusion}

Investigations in North Africa and Eurasia show that mollusk remains offer valuable insights about ancient environments and human subsistence. In Africa, south of the Sahara, terrestrial gastropods have been underreported and alternative interpretations of their use poorly developed by archaeologists. In eastern Africa, the remains of land snails are common finds at Holocene archaeological sites. Contemporary observations coupled with critical considerations of archaeological remains can yield alternative interpretations of the presence and patterning of land snail shell. Ethnographic observations of communities in northeastern Tanzania document a wide range of everyday human uses and special purposes for terrestrial gastropods, a "first step" toward a robust ethnoarchaeology of land snails in East Africa (see Msemwa 1994 for marine mollusks).

At the very least, an ethnoarchaeomalacology of A. fulica (and all durable land snails) raises new and important questions about an almost wholly overlooked type of material find documented at Late Holocene human settlements in East Africa. But, researchers can achieve more than this by skillfully combining ethnographic investigation, heightened awareness and comprehension of land snails and indigenous ethnomalacologies, and archaeological practice receptive to the critical use of analogy. Working with and among African communities enables an ethnoarchaeomalacology that can remake
African pasts by attending to the socially embedded nature of objects.

\section{Acknowledgements}

I offer gratitude to Dr. Peter Kasigwa and Samiu Mbegu for their respective assistance with the laboratory and field aspects of this project.

\section{Declarations}

Permissions: Tanzania Commission for Science and Technology (COSTECH) and the Antiquities Division, Ministry of Natural Resources and Tourism, Tanzania provided research clearances.

Sources of funding: A Fulbright-Hays Doctoral Dissertation Research Abroad Award supplied funding for field study and laboratory analyses in Tanzania.

Conflicts of Interest: None declared.

\section{References Cited}

Biginagwa, T. 2012. Historical Archaeology of the 19th Century Caravan Trade in North-Eastern Tanzania: A Zooarchaeological Perspective. Unpublished Doctoral Dissertation, Department of Archaeology, University of York, York, United Kingdom.

Brown, J. 1995. Traditional Metalworking in Kenya. Oxbow, London, United Kingdom.

Claassen, C. 1998. Shells. Cambridge University Press, Cambridge, United Kingdom.

Collet, D. 1985. The Spread of Early Iron Producing Communities in Eastern Africa. Unpublished Doctoral Dissertation, Department of Archaeology, University of Cambridge, Cambridge, United Kingdom.

Emberton, K., T. Pearce, P. Kasigwa, P. Tattersfield, and Z. Habibu. 1997. High Diversity and Regional Endemism in Land-Snails of Eastern Tanzania. Biodiversity and Conservation 6:1123-1136. DOI:10.1023/A:1018384101789.

Girod, A. 2003. The Holocene Molluscs of Edera Cave (Aurisina, Northeastern Italy): Qualitative and Spatial Analyses, 1990-1997 Excavations. Atti Società per la Preistoria e Protostoria della Regione FriuliVenezia Giulia 13:35-55.

Goodfriend, G. 1992. The Use of Land Snail Shells in Paleoenvironmental Reconstruction. Quaternary 
Science Reviens 11:665-685. DOI:10.1016/02773791(92)90076-K.

Gutierrez Zugasti, F. 2011. Early Holocene Land Snail Exploitation in Northern Spain: The Case of La Fragua Cave. Environmental Archaeology 16:3648. DOI:10.1179/146141010X12640787648306.

Kasigwa, P., A. Mremi, and J. Allen. 1983. Predation by Mongooses, Rodents and Snails on Sitala jenynsi (Pfr.), Achatina fulica Bowdich and other Land Snails in Coastal Tanzania. Journal of the East Africa Natural History Society and National Museum 179:1-9.

Lubell, D. 2004. Prehistoric Edible Land Snails in the Circum-Mediterranean: The Archaeological Evidence. In Petits Animaux et Sociétés Humaines. Du Complément Alimentaire Aux Ressources Utilitaires, edited by J.-J. Brugal and J. Desse, pp. 77-98. XXIVe Rencontres Internationales D'Archéologie et D'Histoire d'Antibes, Éditions APDCA, Antibes.

Lubell D., F. Hassan, A. Gautier, and J. Ballais. 1976. The Capsian Escargotières. Science 191:910-920. DOI:10.1126/science.191.4230.910.

Matteucci, R., G. Belluomini, and L. Manfra. 2007. Late Holocene Environmental Change in Coastal Southern Somalia Inferred from Achatina and Rhizoliths. Journal of African Earth Sciences 49:79-89. DOI:10.1016/j.jafrearsci.2007.07.001.

Msemwa, P. 1994. An Ethnoarchaeological Study on Shellfish Collecting in a Complex Urban Setting. Unpublished Doctoral Dissertation, Department of Anthropology, Brown University, Providence, RI.

Pilsbry, H. 1919. A Review of the Land Mollusca of the Belgian Congo Chiefly Based on the Collections of the American Museum Congo Expedition, 1909-1915. Bulletin of the American Museum of Natural History 40:1-370.
Shipton, C., A. Crowther, N. Kourampas, M. Prendergast, M. Horton, K. Douka, J.-L. Schwenninger, P. Faulkner, E. Quintana Morales, M. Langley, R. Tibesasa, L. Picornell-Gelabert, E. Wilmsen, C. Doherty, M.-A. Veall, A. Ali, M. Petraglia, and N. Boivin. 2016. Reinvestigation of Kuumbi Cave, Zanzibar, Reveals Later Stone Age Coastal Habitation, Early Holocene Abandonment and Iron Age Reoccupation. Azania 51:197-233. DOI:10.1080/0067270X.2016.1173308.

Soper, R. 1967. Iron Age Sites in North-Eastern Tanzania. Azania 2:19-38. DOI:10.1080/00672706709511438.

Tattersfield, P., M. Seddon, C. Meena, N. Kayumbo, and P. Kasigwa. 1998. Ecology and Conservation of the Land-Snails of the Eastern Arc Mountains. Journal of East African Natural History 87:119-138. DOI:10.2982/0012-8317(1998)87[119:EACOTL] 2.0.CO.

Verdcourt, B. 1952. Observations on the Ecology of the Land and Freshwater Mollusca of North-East Tanganyika. Tanganyika Notes and Records 33:67-82.

Verdcourt, B. 1972. The Zoogeography of the NonMarine Mollusca of East Africa. Journal of Conchology 27:291-348.

Walsh, M. 2015. Notes on Achatina Shells collected on Unguja Island, Zanzibar, July 2015. Report in Papers of Martin Walsh. Zanzibar, Tanzania.

Walz, J. 2010a. Molluscs and Late Holocene Archaeology in East Africa. Archaeo+Malacology Newsletter 17:1-3.

Walz, J. 2010b. Route to a Regional Past: An Archaeology of the Lower Pangani (Ruvu) Basin, Tanzania, 500-1900 C.E. Unpublished Doctoral Dissertation, Department of Anthropology, University of Florida, Gainesville, FL. 